Article

\title{
A Powerful LAMP Weapon against the Threat of the Quarantine Plant Pathogen Curtobacterium flaccumfaciens pv. flaccumfaciens
}

\author{
Stefania Tegli ${ }^{1, *(1)}$, Carola Biancalani ${ }^{1}$, Aleksandr N. Ignatov ${ }^{2}\left(\mathbb{C}\right.$ and Ebrahim Osdaghi ${ }^{3}$ (i) \\ 1 Laboratorio di Patologia Vegetale Molecolare, Dipartimento di Scienze e Tecnologie Agrarie, \\ Alimentari Ambientali e Forestali (DAGRI), Università degli Studi di Firenze, Via della Lastruccia 10, \\ 50019 Sesto Fiorentino (Firenze), Italy; carolabiancalani@virgilio.it \\ 2 Agrarian and Technological Institute (ATI), Peoples' Friendship University of Russia, \\ Miklukho-Maklaya str.8, 117198 Moscow, Russia; an.ignatov@gmail.com \\ 3 Department of Plant Protection, University of Tehran, Karaj 31587-77871, Iran; eosdaghi@ut.ac.ir \\ * Correspondence: stefania.tegli@unifi.it; Tel.: +39-0554573427
}

Received: 31 August 2020; Accepted: 28 October 2020; Published: 31 October 2020

\begin{abstract}
Curtobacterium flaccumfaciens pv. flaccumfaciens (Cff) is a Gram-positive phytopathogenic bacterium attacking leguminous crops and causing systemic diseases such as the bacterial wilt of beans and bacterial spot of soybeans. Since the early 20th century, Cff is reported to be present in North America, where it still causes high economic losses. Currently, Cff is an emerging plant pathogen, rapidly spreading worldwide and occurring in many bean-producing countries. Infected seeds are the main dissemination pathway for Cff, both over short and long distances. Cff remains viable in the seeds for long times, even in field conditions. According to the most recent EU legislation, Cff is included among the quarantine pests not known to occur in the Union territory, and for which the phytosanitary inspection consists mainly of the visual examination of imported bean seeds. The seedborne nature of Cff combined with the globalization of trades urgently call for the implementation of a highly specific diagnostic test for Cff, to be routinely and easily used at the official ports of entry and into the fields. This paper reports the development of a LAMP (Loop-Mediated Isothermal Amplification) specific for Cff, that allows the detection of Cff in infected seeds, both by fluorescence and visual monitoring, after $30 \mathrm{~min}$ of reaction and with a detection limit at around $4 \mathrm{fg} / \mu \mathrm{L}$ of pure Cff genomic DNA.
\end{abstract}

Keywords: Loop-Mediated Isothermal Amplification; LAMP; Curtobacterium flaccumfaciens pv. flaccumfaciens; bacterial wilt of bean; tan spot of soybean; quarantine plant pathogen; molecular diagnostics

\section{Introduction}

Curtobacterium flaccumfaciens pv. flaccumfaciens (Cff) is a highly damaging plant pathogenic Gram-positive bacterium, causing serious diseases among several cultivated and wild leguminous species. The host range of this pathogen includes common bean (Phaseolus vulgaris L.), cowpea (Vigna unguiculata L.), mung bean (V. radiata L.), and soybean (Glycine max L.) [1,2]. Cff was firstly described in 1922 in the USA and was later recorded in Canada, Mexico, South America, Australia and, more recently, in Iran $[1,3,4]$. Cff was listed into the A2 list of the European and Mediterranean Plant Protection Organization (EPPO) for pests recommended for quarantine regulation since 1975 [5], and since 2019 it is included in the List 1, Annex II A, of quarantine pathogens for EU that have not known to occur in the Union territory [6,7]. Currently, in Europe Cff is reported to be present in Russia and Turkey, although with a restricted distribution $[5,8]$. However, recent sporadic reports have been recorded in Spain, 
Germany, and Austria, with disease outbreaks occurring on bean, soybean, and cowpea, respectively, which have been promptly followed by Cff eradication $[5,9,10]$. These outbreaks raised great concern among the EU Member States, for which the dry pulse crop area has grown considerably since 2013 as a result of the current Common Agricultural Policy (CAP) towards a more sustainable agriculture [11], and where the climatic conditions are favorable to the establishment of Cff [2]. This quarantine phytopathogen is also a potential threat to the wide biodiversity of the many bean cultivars and other legumes originating from Europe. Most of these local varieties are promoted worldwide as traditional products. They are marked by specific European food quality logos, and often represent an essential income in rural areas.

In this overall frame, the seedborne nature of $C f f$ is a serious concern as it allows the rapid spread of this plant pathogen over long distances, through the movement of infected seeds on a global market scale [12-14]. Although most Cff-infected seeds are asymptomatic, the current testing methods are still based on the visual examination of seed crops and harvested seeds [1]. Some semi-selective culture media and immunological tests have also been reported for Cff, but they generally have low sensitivity and specificity, and are time-consuming [for a recent review, 4]. Currently, among the PCR-based assays developed so far for Cff $[15,16]$, the primer pair CffFOR2/CffREV4 has been demonstrated to be highly effective and sensitive for the detection of Cff in contaminated bean seeds [16-18], and in/on alternative host plants and weeds [19-22].

As no effective chemicals against this pathogenic bacterium are known, the availability of a specific and sensitive diagnostic test for the rapid detection of Cff on plant materials, possibly at the port of entry and into the fields, is a pivotal step towards the successful prevention of disease outbreaks. Traditional PCR-based assays are mostly unsuitable for direct field use, as well as for less well-equipped laboratories. Conversely, Loop-Mediated Isothermal Amplification (LAMP) is a technique particularly useful for on-site testing [23]. The LAMP reaction is isothermal, and thus can be performed in a simple heating block or a water bath, without the need for any specialized thermal cycler. In addition, positive results can be observed in less than an hour with the naked eye or by using a portable fluorescent reader, thus removing the post-amplification steps of electrophoresis, gel staining, and imaging. Recently, several LAMP assays have been successfully developed for some plant pathogenic bacteria [24-28], and sometimes also tested at field level [24,27].

This paper describes the development of a simple, sensitive, and highly specific LAMP assay for the cost- and time-saving quali-quantitative detection of Cff, whose effectiveness was successfully compared to the conventional PCR-based method adopted so far for this phytopathogen. The LAMP-specific primers here designed are targeting the Cff genomic region specifically amplified with the primer pair CffFOR2/CffREV4 on any C. flaccumfaciens isolate pathogenic on bean, regardless of its host of isolation. This LAMP assay was shown to be highly effective in detecting Cff in infected bean plants and seeds.

According to its performances, this LAMP method is a valuable diagnostic tool, which can be easily applied where an early and rapid diagnosis of the presence of this quarantine phytopathogen on bean seeds is required.

\section{Materials and Methods}

\subsection{Bacterial Strains and Growth Conditions}

The bacterial strains used in this study are listed in Table 1. The Cff strains include several different colony variants of this pathogen, that are yellow-, red- and orange-pigmented strains [21]. In addition to Cff strains isolated from leguminous plants and from several alternative hosts, C. flaccumfaciens isolates that are not pathogenic on beans, and the type strains of the four other $C$. flaccumfaciens pathovars betae, ilicis, oortii, and poinsettiae, were also used. Furthermore, closely related species (i.e., Clavibacter michiganensis subsp. michiganensis $(\mathrm{Cmm})$ ), as well as other important bean phytopathogens (i.e., Pseudomonas savastanoi pv. phaseolicola (Psp) and Xanthomonas axonopodis pv. phaseoli (Xap)), were also tested (Table 1). 
Table 1. Bacterial strains used in this study.

\begin{tabular}{|c|c|c|c|c|c|c|}
\hline Bacteria & Strain & Source $^{a}$ & $\begin{array}{c}\text { Host of } \\
\text { Isolation } \\
\end{array}$ & Pathogenicity ${ }^{b}$ & LAMP $^{\mathrm{c}}$ & PCR $^{c}$ \\
\hline \multirow{35}{*}{$\begin{array}{l}\text { Curtobacterium flaccumfaciens } \\
\text { pv. flaccumfaciens (Cff) }\end{array}$} & Type & ICMP 2584 & Common bean & + & + & + \\
\hline & $50 \mathrm{R}$ & ICMP 22071 & Common bean & + & + & + \\
\hline & $80 \mathrm{O}$ & ICMP 22069 & Common bean & + & + & + \\
\hline & $\mathrm{Cb} 222$ & ICMP 21399 & Common bean & + & + & + \\
\hline & Cb302 & - & Common bean & + & + & + \\
\hline & Cb926 & - & Common bean & + & + & + \\
\hline & Cff110 & - & Common bean & + & + & + \\
\hline & Cff137 & ICMP 22066 & Common bean & + & + & + \\
\hline & Cff151 & - & Common bean & + & + & + \\
\hline & Cff153 & - & Common bean & + & + & + \\
\hline & Cff155 & - & Common bean & + & + & + \\
\hline & Cff156 & - & Common bean & + & + & + \\
\hline & Cff178 & NCPPB 178 & Common bean & + & + & + \\
\hline & Cff558 & NCPРB 558 & Common bean & + & + & + \\
\hline & Cff567 & NCCPB 567 & Common bean & + & + & + \\
\hline & Cff1412 & NCPРB 1412 & Common bean & + & + & + \\
\hline & Cff1751 & NCPРB 1751 & Common bean & + & + & + \\
\hline & $10 \mathrm{eg}$ & ICMP 22079 & Eggplant & + & + & + \\
\hline & Cw101 & - & Cowpea & + & + & + \\
\hline & Cw110 & - & Cowpea & + & + & + \\
\hline & Eg502 & ICMP 22055 & Eggplant & + & + & + \\
\hline & Eg505 & ICMP 22054 & Eggplant & + & + & + \\
\hline & P701 & ICMP 22078 & Bell pepper & + & + & + \\
\hline & $\mathrm{P} 99 \mathrm{O}$ & ICMP 22053 & Bell pepper & + & + & + \\
\hline & Tom50 & ICMP 22062 & Tomato & + & + & + \\
\hline & Tom803 & ICMP 22083 & Tomato & + & + & + \\
\hline & Tom806 & ICMP 22059 & Tomato & + & + & + \\
\hline & Tom930 & ICMP 22057 & Tomato & + & + & + \\
\hline & Tom999 & ICMP 22082 & Tomato & + & + & + \\
\hline & CFgs5 & - & Soybean & + & + & + \\
\hline & CFgs6 & - & Soybean & + & + & + \\
\hline & CFgs12 & - & Soybean & + & + & + \\
\hline & CFgs14 & - & Soybean & + & + & + \\
\hline & CFgs15 & - & Soybean & + & + & + \\
\hline & CFgs18 & - & Soybean & + & + & + \\
\hline \multirow{6}{*}{ Curtobacterium flaccumfaciens } & Tom827 & ICMP 22084 & Tomato & - & - & - \\
\hline & Xeu15 & ICMP 21400 & Chilli pepper & - & - & - \\
\hline & Cmmeg20 & ICMP 22056 & Eggplant & - & - & - \\
\hline & CFha4 & - & Sunflower & - & - & - \\
\hline & CFha5 & - & Sunflower & - & - & - \\
\hline & CFha8 & - & Sunflower & - & - & - \\
\hline $\begin{array}{c}\text { Curtobacterium flaccumfaciens } \\
\text { pv. betae }(\mathrm{Cfb})\end{array}$ & Type & ICMP 2594 & Red beet & - & - & - \\
\hline $\begin{array}{c}\text { Curtobacterium flaccumfaciens } \\
\text { pv. ilicis (Cfi) }\end{array}$ & Type & ICMP 2608 & American holly & - & - & - \\
\hline $\begin{array}{c}\text { Curtobacterium flaccumfaciens } \\
\text { pv. oortii }(C f o)\end{array}$ & Type & ICMP 2632 & Tulip & - & - & - \\
\hline
\end{tabular}


Table 1. Cont.

\begin{tabular}{|c|c|c|c|c|c|c|}
\hline Bacteria & Strain & Source $^{a}$ & $\begin{array}{l}\text { Host of } \\
\text { Isolation }\end{array}$ & Pathogenicity $b$ & LAMP c & PCR $^{c}$ \\
\hline $\begin{array}{c}\text { Curtobacterium flaccumfaciens } \\
\text { pv. poinsettiae }(C f p)\end{array}$ & Type & ICMP 2566 & Poinsettia & - & - & - \\
\hline $\begin{array}{l}\text { Clavibacter michiganensis subsp. } \\
\text { michiganensis }(\mathrm{Cmm})\end{array}$ & Type & ICMP 2550 & Tomato & - & - & - \\
\hline $\begin{array}{l}\text { Pseudomonas savastanoi } \\
\text { pv. phaseolicola }(P p h)\end{array}$ & Type & NCPPB 1449 & Lablab purpureus & - & - & - \\
\hline $\begin{array}{l}\text { Xanthomonas axonopodis } \\
\text { bbpv. phaseoli (Xap) }\end{array}$ & Type & NCPPB 3035 & Common bean & - & - & - \\
\hline
\end{tabular}

Bacterial strains were routinely grown at $26^{\circ} \mathrm{C}$ on Luria Bertani (LB) [29] medium both as liquid and solid cultures, while $C f f$ strains were specifically plated on nutrient broth yeast extract agar medium (NBY) [30]. Bacteria were preserved for long-term storage at $-80^{\circ} \mathrm{C}$ in LB broth, supplemented with $40 \%$ glycerol $(w / v)$, and subcultured when required.

\subsection{Bacterial DNA Extraction and Thermal Lysis}

Bacterial DNA extraction and purification were carried out using the Puregene ${ }^{\circledR}$ DNA Isolation Kit (Qiagen $\mathrm{GmbH}$, Hilden, Germany), as recommended by the manufacturer. The yield and quality of the extracted DNA were evaluated both spectrophotometrically by using Nanodrop ND-100 (Nanodrop Technologies, Waltham, MA, USA), and visually by standard agarose gel electrophoresis ( $1 \%$ agarose $(w / v)$ in TBE 1X) [31], respectively. The DNA was then stored at $-20^{\circ} \mathrm{C}$ until needed. Bacterial DNA was also obtained by thermal lysis of single colonies, each picked up from fresh agar plates with a sterile loop and diluted in sterile bidistilled water $\left(100 \mu \mathrm{L} /\right.$ pellet), incubated at $95^{\circ} \mathrm{C}$ for $15 \mathrm{~min}$, and then immediately cooled on ice. After a quick spin in a microcentrifuge, $5 \mu \mathrm{L}$ lysate was directly used in amplification reactions as a template.

\subsection{Primer Design}

Several primer sets for the specific LAMP amplification of Cff DNA were designed by using the Primer Explorer V5 software (Eiken Chemicals, Tokyo, Japan) (http://primerexplorer.jp/lampv5e), targeting the same $306 \mathrm{bp}$ nucleotide sequence on which the conventional PCR-based protocol used for Cff identification was also based [16,17]. A manual check for the best default program parameters and a BLAST search for potential aspecific homologies (http://www.ncbi.nlm.nih.gov/blast) were also carried out. For comparison, the primer pair CffFOR2/CffREV4 was also used [16]. Primers were synthesized and HPLC-purified at Eurofins (Hamburg, Germany).

\subsection{LAMP Reaction}

The $25 \mu \mathrm{L}$ LAMP reaction mixture contained $15 \mu \mathrm{L}$ of GspSSD Isothermal Mastermix ISO-001 (Optigene, Horsham, UK), the CffF3 and CffB3 outer primers (200 nM each), the CffFIP and CffBIP inner primers ( $800 \mathrm{nM}$ each), and, as a template, a $5 \mu \mathrm{L}$ solution of purified genomic DNA from Cff strains reported in Table 1, at a concentration depending on the experimental purposes. In negative controls, the template consisted of sterilized molecular grade bidistilled water. Cross-reactivity with non-target species was tested, by using purified DNA from non-pathogenic C. flaccumfaciens strains, or closely related bacteria (i.e., $\mathrm{Cmm}$ ), or other plant pathogenic bacteria occurring on beans (i.e., Psp and Xap). The optimized reaction was run at $63^{\circ} \mathrm{C}$ for $30 \mathrm{~min}$ in the $\mathrm{CFX} 96^{\mathrm{TM}}$ real-time fluorometer (Bio-Rad, Hercules, CA, USA), with fluorescence data recorded at $60 \mathrm{~s}$ time intervals. The LAMP generated amplicons $(5 \mu \mathrm{L} /$ reaction) were also endpoint analyzed on agarose gel ( $2 \%$ agarose $(w / v)$ in TBE $1 X)$ [31], 
with $5 \mu \mathrm{L}$ reaction/well, then stained with ethidium bromide $(0.5 \mu \mathrm{g} / \mathrm{mL})$, and UV-visualized by using the Molecular Imager ${ }^{\circledR}$ Gel Doc ${ }^{\mathrm{TM}}$ XR System (Bio-Rad).

A colorimetric LAMP assay was also performed, by using the WarmStart Colorimetric LAMP $2 \times$ master mix (New England BioLabs, Ipswich, MA, USA), according to the manufacturer's recommendations, and carried out at $63^{\circ} \mathrm{C}$ for $30 \mathrm{~min}$ in a $25 \mu \mathrm{L}$ final reaction. Sterilized molecular grade bidistilled water was included in each analysis as a negative control. Six independent experiments were conducted with three replicates for each sample.

\subsection{Detection of Cff in Artificially and Naturally Infected Bean Plant Materials}

The in planta performances of the newly developed Cff-specific LAMP assay have been assessed both on bean plants artificially inoculated with Cff and on naturally Cff-infected bean seeds of the Iranian cultivar (cv.) Pak.

Artificial inoculations on certified commercial bean seeds of the Italian cv. Cannellino (Linea Mediterranea srl, Pomezia-Roma, Italy) were performed by using the hilum injury method [32]. Each seed was injured by piercing the hilum with a sterile needle. Then, bean seeds were soaked for $1 \mathrm{~h}$ in a fresh Cff bacterial suspension $\left(\mathrm{OD}_{600}=0.5\right.$, corresponding approximately to $10^{8}$ colony-forming unit $/ \mathrm{mL}(\mathrm{CFU} / \mathrm{mL})$ ). Seeds used as negative controls were soaked in sterile physiological solution (SPS; $0.85 \% \mathrm{NaCl}$ in bidistilled water). Inoculated and uninoculated bean seeds were then separately sown in $15 \mathrm{~cm}$ diameter plastic pots (1 seed/pot) with Cornell peat-lite mix, and incubated in a growth chamber with a $16 \mathrm{~h}$ photoperiod and temperature of $22 \pm 2{ }^{\circ} \mathrm{C}$. Plants were monitored daily for the appearance of symptoms, and at 14 days post-infection (d.p.i.), three true leaves from each Cff-inoculated and control plant were detached and used for DNA extraction, which was carried out with NucleoSpin ${ }^{\circledR}$ Plant II (Macherey-Nagel, Düren, Germany), according to the manufacturer's recommendations. The resulting total genomic material contained both the host plant (bean) DNA and the bacterial DNA (Cff). This DNA was then used as a template for both conventional PCR and LAMP assays. Three independent experiments were performed, with six replicates for each experimental condition for each run.

Samples (10 seeds each, corresponding to about $4.225 \pm 0.350 \mathrm{~g}$ ) of healthy-looking and symptomatic Cff-naturally infected bean seeds cv. Pak were separately washed three times in sterile distilled water. These seeds were derived from a Cff-infested area in Iran. Cff-free certified seeds of the same cultivar were used as a negative control. Each sample was then finely grounded, and transferred into $20 \mathrm{~mL}$ of SPS, under shaking conditions for 12-14 h. Any seed particle and residue were then eliminated by filtering the suspension on a sterile gauze, and the filtrate was then centrifugated at $6000 \times \mathrm{g}$, for $20 \mathrm{~min}$ at $4{ }^{\circ} \mathrm{C}$. The supernatant was discharged, while the pellet was resuspended in $1 \mathrm{~mL}$ SPS, and then directly used for the amplification tests. Three independent experiments were performed, and six samples for each condition (i.e., healthy-looking and symptomatic Cff-infected seeds, and certified Cff free seeds) at each run were used.

\section{Results}

\subsection{Design and Selection of LAMP Primers}

As a target sequence for LAMP primer design, the highly conserved $306 \mathrm{pb}$ DNA fragment amplified by the Cff specific endpoint PCR-based test [4,16,17] (GenBank Accession Numbers AJ307048, AJ307049, and AJ307051) was selected. Among the primers generated by Primer Explorer V5, a set of four LAMP primers was chosen as the most appropriate candidate, according to several key parameters, such as GC content, melting temperature (Tm), distances between primers, and stability of primer ends expressed as free energy $(\Delta G)$. These primers were also in silico analyzed by BLAST searches, and no homology hits were found but the expected Cff target sequence (data not shown).

The selected LAMP primers recognize six distinct regions on the target sequence, and consist of the two outer primers named CffF3 and CffB3, and the two inner hybrid primers named CffFIP 
and $C f f B I P(C f f F I P=$ sequences F1c + F2; $C f f B I P=$ sequences B1c + B2 $)$. The primer sequences and their main features are reported in Table 2. Their annealing sites on the target sequence are shown in Figure S1. The stability of the ends of the selected LAMP primers, expressed as $\Delta \mathrm{G}$, appeared to be high, in particular to those ends essential as starting points for DNA synthesis. In particular, the $3^{\prime}$ ends of the outer primers CffF3 and CffB3, and of the sequences F2 and B2 of the internal hybrid primers, showed $\Delta \mathrm{G}$ values definitely lower than $-4 \mathrm{Kcal} / \mathrm{mol}$ (Table 2), to guarantee a high degree of stability [33]. Similarly, the $\Delta G$ values for the $5^{\prime}$ ends of the F1c and B1c sequences of the internal primer pair were -5.17 and -5.69 , respectively.

Table 2. Sequences and features of the LAMP primers designed and used in this study for Cff specific detection.

\begin{tabular}{|c|c|c|c|c|c|c|c|}
\hline $\begin{array}{l}\text { Primers } \\
\text { Name }\end{array}$ & Type & $\begin{array}{l}\text { Primer Sequence } \\
\qquad 5^{\prime}-3^{\prime}\end{array}$ & $\begin{array}{l}\text { Length } \\
\text { (bp) }\end{array}$ & $\begin{array}{l}\mathrm{Tm} \\
\left({ }^{\circ} \mathrm{C}\right)\end{array}$ & $\begin{array}{l}\text { GC } \\
(\%)\end{array}$ & $\begin{array}{c}5^{\prime} \Delta \mathrm{G} \\
\text { (kcal/mol) }\end{array}$ & $\begin{array}{c}3^{\prime} \Delta \mathrm{G} \\
\text { (kcal/mol) }\end{array}$ \\
\hline CffF3 & $\begin{array}{l}\text { Forward } \\
\text { outer }\end{array}$ & CGTTAGTGAAGGCTGACGAA & 20 & 59.3 & 50 & -4.51 & -5.26 \\
\hline CffB3 & $\begin{array}{l}\text { Reverse } \\
\text { outer }\end{array}$ & TTCCCGGTGTTCAGTTGAC & 19 & 59.2 & 53 & -6.14 & -4.67 \\
\hline $\begin{array}{c}\text { CffFIP } \\
(\mathrm{F} 1 \mathrm{c}+\mathrm{F} 2)\end{array}$ & $\begin{array}{l}\text { Forward } \\
\text { inner }\end{array}$ & $\begin{array}{l}\text { GTTTGCATCCGTACGGGGCG- } \\
\text { ACTAGCACCGACGGAACC }\end{array}$ & $\begin{array}{c}38 \\
(20+18)\end{array}$ & $\begin{array}{l}65.8 \\
60.6\end{array}$ & $\begin{array}{l}65 \\
61\end{array}$ & $\begin{array}{l}-5.17 \\
-4.18\end{array}$ & $\begin{array}{l}-7.97 \\
-5.46\end{array}$ \\
\hline $\begin{array}{c}\text { CffBIP } \\
(\mathrm{B} 1 \mathrm{c}+\mathrm{B} 2)\end{array}$ & $\begin{array}{l}\text { Reverse } \\
\text { inner }\end{array}$ & $\begin{array}{l}\text { TTCGGTCCTGCAGTTAGTCAGC- } \\
\text { GAATAGTTCGCGGCGTGG }\end{array}$ & $\begin{array}{c}40 \\
(22+18)\end{array}$ & $\begin{array}{l}64.2 ; \\
60.2\end{array}$ & $\begin{array}{l}55 ; \\
61\end{array}$ & $\begin{array}{l}-5.69 \\
-3.08\end{array}$ & $\begin{array}{l}-5.75 \\
-7.18\end{array}$ \\
\hline
\end{tabular}

Finally, primer design is the main challenging step in the development of a new LAMP assay as the probability of secondary structures formation is increased by the high number of primers required (four as a minimum). According to their $\Delta \mathrm{G}$ values, the LAMP primers here designed and selected were predicted to be poorly prone towards the formation of both cross- and self-dimers as well as of hairpins (Table S1).

No additional suitable loop primers were identified using Primer Explorer V5, with the short size of the template as the only limiting factor. However, loop primers have been demonstrated to be not essential for a successful LAMP reaction, although a reduction in amplification times can sometimes be achieved [34-36].

\subsection{Optimization of LAMP Assay for Cff Detection}

The optimal temperature and reaction time of the LAMP assay for Cff detection have been established by using pure DNA of the Cff type strain ICMP 2584 (40 ng/reaction) as template, and accordingly to the assessment of both gel electrophoresis and real-time fluorescence data.

Pure Cff ICMP $2584^{\mathrm{T}}$ DNA was tested at six different amplification temperatures, within the range $62-67^{\circ} \mathrm{C}$, and the reaction time was $30 \mathrm{~min}$ as recommended by the manufacturer. The typical ladder-like DNA multiple bands of LAMP reaction have been detected on an agarose gel in positive samples for all the tested amplification temperatures (Figure 1A).

No unspecific amplifications or primers cross-annealing were observed, regardless of the reaction temperature. Similarly, the real-time fluorescence monitoring showed successful reactions to take place within the range $62^{\circ} \mathrm{C}-67^{\circ} \mathrm{C}$ on positive samples, and the plateau was reached after $15 \mathrm{~min}$ (Figure 1B). The reaction threshold times ranged from 5 to $9 \mathrm{~min}$ for amplification temperatures between $62{ }^{\circ} \mathrm{C}$ and $65^{\circ} \mathrm{C}$, while higher times (i.e., 12 and $15 \mathrm{~min}$ ) were needed at higher temperatures (i.e., $66^{\circ} \mathrm{C}-67^{\circ} \mathrm{C}$ ) (Figure 1). Accordingly, the optimal conditions established for this Cff-specific LAMP assay were $63{ }^{\circ} \mathrm{C}$ with a 30-min running time (corresponding to 30 cycles of $1 \mathrm{~min} / \mathrm{each}$ ), then used for all the following applications. 
$\mathbf{A}$

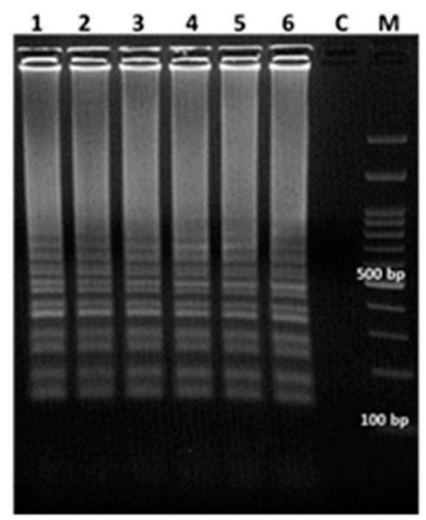

\section{B}

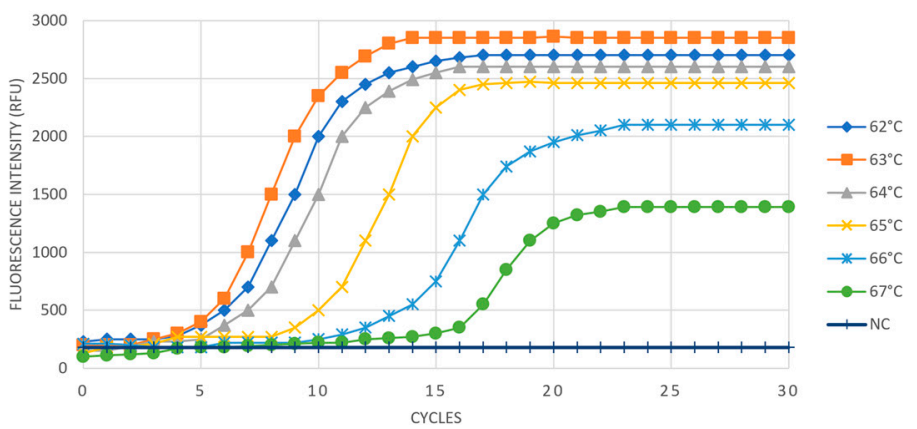

Figure 1. Optimization of LAMP reaction for Cff DNA detection. Isothermal amplification was carried out on Cff ICMP $2584^{\mathrm{T}}$ DNA (40 ng/reaction) used as a template, and at temperatures ranging from $62{ }^{\circ} \mathrm{C}$ to $67^{\circ} \mathrm{C}$. Data assessment was based on $2 \%$ agarose gel electrophoresis analysis (A) and real-time fluorescence monitoring (B). (A) M - Gene Ruler 100 pb Plus DNA Ladder; C = negative control; lanes 1 to 6: amplicons in the temperature range $62{ }^{\circ} \mathrm{C}-67^{\circ} \mathrm{C}$. (B) Optimization of reaction time, according to real-time fluorescence amplification plots; $\mathrm{NC}=$ negative control. 1 cycle $=1 \mathrm{~min}$ reaction.

\subsection{Specificity and Sensitivity of the LAMP Assay for Cff Detection}

The specificity of the LAMP primers designed here was assessed by testing, as a template, the purified genomic DNA (40 ng/reaction) from 35 Cff strains, having different geographical origin and isolated from several different host plants, including P. vulgaris L., V. unguiculata L., Capsicum annum L., Solanum lycopersicum L., and S. melongena L. Moreover, DNAs from non-target phytopathogenic bacteria were also included, such as several $C$. flaccumfaciens strains, or the type strains from the C. flaccumfaciens pathovars betae, ilicis, ooorti, and poinsettiae, or bacteria taxonomically related to Cff (i.e., $\mathrm{Cmm}$ ), or bacteria that are pathogenic on common bean and seedborne (i.e., Psp and Xap) (Table 1). All the Cff strains tested here gave positive results, as assessed by both real-time fluorescence monitoring and gel electrophoresis analysis. No cross-reactivity or aspecific amplification were found to occur when DNA from non-target bacteria species was used as a template (Table 1). Therefore, this LAMP assay for Cff detection has a specificity fully comparable with that of the existing conventional PCR test for this quarantine phytopathogen $[16,17]$ (Table 1).

In order to evaluate the analytical sensitivity of the LAMP assay developed here, the smallest known amount of target DNA detected in each test sample was assessed. Several ten-fold serial dilutions of Cff ICMP $2584^{\mathrm{T}}$ pure genomic DNA were used as a template, prepared in sterilized molecular grade bidistilled water and ranging from $100 \mathrm{fg} /$ reaction to $100 \mathrm{ng} /$ reaction, in a $25 \mu \mathrm{L}$ final volume. The fluorescence-based real-time monitoring showed that this LAMP reaction is able to detect Cff genomic DNA down to $0.1 \mathrm{pg} /$ reaction after $20 \mathrm{~min}$. As expected, the amplification time was shorter as the DNA template concentration increased, and positive signals were obtained just after 15 min with $1 \mathrm{pg} /$ reaction Cff DNA as a template (Figure 2A). The agarose electrophoresis analysis of LAMP products confirmed these data. The characteristic ladder-like DNA bands were observed when Cff DNA was used as a template in the range of $100 \mathrm{ng}-100 \mathrm{fg}$ per reaction (Figure 2B). 
A

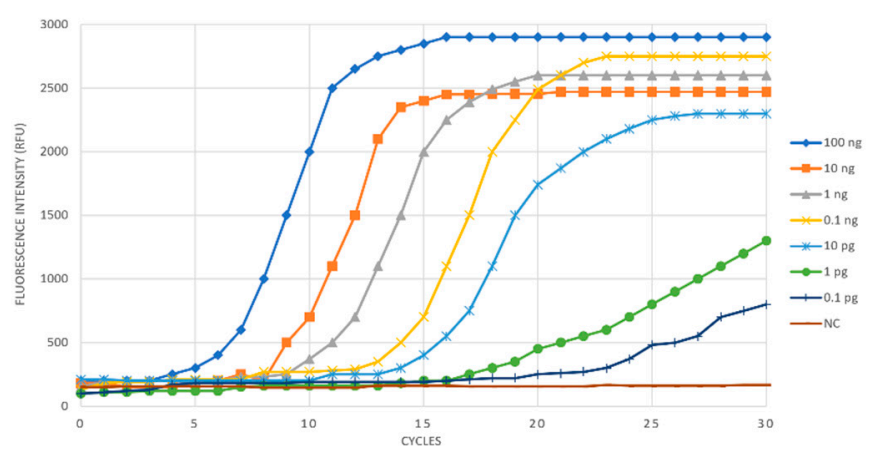

B

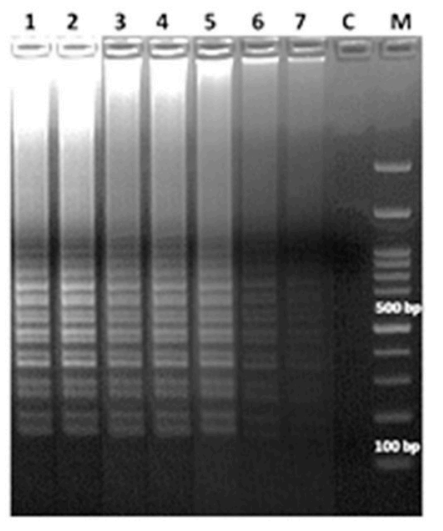

Figure 2. Determination of the analytical sensitivity of the LAMP assay for Cff detection. Isothermal amplifications were carried out on tenfold diluted test samples of Cff ICMP $2584^{\mathrm{T}}$ DNA (from $100 \mathrm{ng}$ to $100 \mathrm{fg}$ per $25 \mu \mathrm{L}$ reaction). Data assessment was based on (A) real-time fluorescence monitoring and (B) $2 \%$ agarose gel electrophoresis analysis of the LAMP products. (A) NC = negative control. 1 cycle $=1$ min reaction. (B) Lanes 1-7: $100 \mathrm{ng}, 10 \mathrm{ng}, 1 \mathrm{ng}, 0.1 \mathrm{ng}, 10 \mathrm{pg}, 1 \mathrm{pg}$, and $0.1 \mathrm{pg}$ of genomic DNA/reaction, respectively; M - Gene Ruler 100 pb Plus DNA Ladder; C = negative control.

\subsection{LAMP Detection of Cff on Artificially and Naturally Infected Bean Samples}

Firstly, bean plants cv. "Cannellino" artificially inoculated with Cff ICMP $2584^{\mathrm{T}}$ by hilum injured method were used to validate the LAMP assay for Cff detection. Initially, the DNA extracted from both Cff inoculated and uninoculated bean plants were subjected to conventional PCR, carried out using the primer pair CffFOR2-CffREV4 [16,17]. Positive results were obtained only for Cff inoculated plant samples, where the characteristic single $306 \mathrm{bp}$ amplicon was specifically visualized on agarose gel (Figure 3A).

A

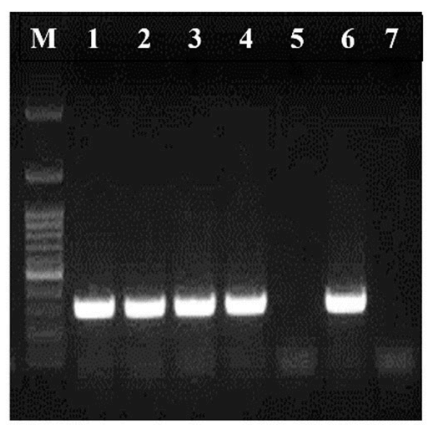

B

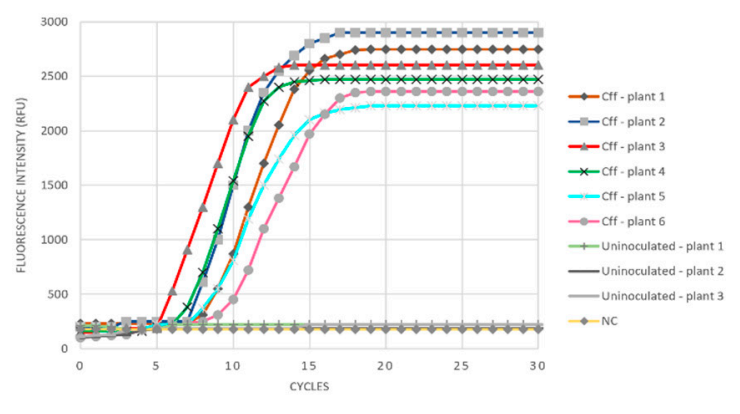

Figure 3. LAMP assay results from Cff-artificially infected bean plants cv. Cannellino. The Cff type strain ICMP 2584 was used for artificial inoculation. (A) Cff infection was confirmed by conventional PCR carried out using the primer pair CffFOR2/CffREV4. Lanes: 1, 2, 3, 4: Cff-inoculated bean plants; 5: uninoculated bean plant; 6: Cff ICMP 2584 ${ }^{\mathrm{T}}$ pure DNA; 7: negative control, sterilized molecular grade water as a template; M - Gene Ruler 100 pb Plus DNA Ladder. (B) Real-time monitoring of LAMP reaction for Cff detection on bean plants artificially inoculated with Cff ICMP $2584^{\mathrm{T}}$ or with SPS. Sterilized molecular grade water was used as a negative control (NC).

When the LAMP reaction was monitored by fluorescent real-time analysis, the DNA extracted from every artificially Cff-inoculated plant showed a positive amplification curve, just after 5 min. No amplification signals were recorded using, as a template, the DNA extracted from control uninoculated plants (Figure 3B). Data were further confirmed by agarose gel electrophoresis analysis of the LAMP products (data not shown). 
This LAMP assay has been evaluated also on naturally Cff-infected bean seeds, where the presence of this phytopathogen is often asymptomatic. To this aim, bean seeds belonging to the cv. "Pak", collected in Iran from fields previously assessed as Cff-infected, were used for DNA extraction [17], and then tested by conventional PCR with the primer pair CffFOR2/CffREV4 and by LAMP fluorescence real-time monitoring (data not shown). The infection level was about $72 \%$. Seeds to be considered as Cff infected were those testing positive both by PCR and LAMP assays, regardless of the presence of any symptoms.

A protocol for the direct visual detection of LAMP results was also developed. The $\mathrm{pH}$ indicator dye used here turned from pink to yellow, as a consequence of the $\mathrm{pH}$ value decrease upon DNA amplification [37]. This protocol for visual LAMP was applied and tested on naturally Cff-infected bean seeds belonging to the cv. "Pak", and highly reproducible results were obtained. As shown in Figure 4, the colorimetric visual readouts of LAMP results were positive within a time period of 15 to $30 \mathrm{~min}$ after the start of the incubation at $63^{\circ} \mathrm{C}$, when DNA extracted from the Cff-naturally infected bean seeds cv. "Pak" was used as a template, regardless of whether or not these seeds showed or not any symptoms.

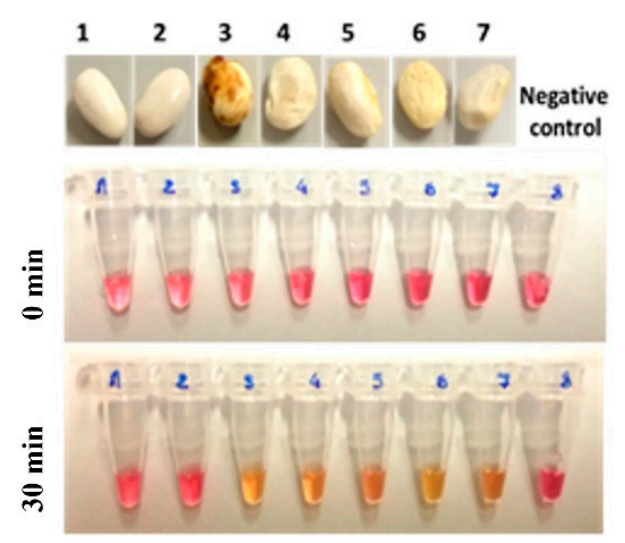

Figure 4. Visual detection of LAMP products obtained with bean seed samples cv. "Pak" for Cff detection. Visual detection of LAMP products from bean seed samples cv. "Pak" for Cff detection. Positive samples show a color change, from pink (negative samples) to yellow. Uninfected (samples 1 and 2) and naturally Cff-infected (samples 3, 4, 5, 6, 7). Molecular grade water was used as a template in negative controls (sample 8).

The detection rate was similar to that previously obtained by conventional PCR and LAMP fluorescence monitoring. Samples containing, as a template, DNA from Cff-free certified seeds cv. "Pak" always scored as negative. Controls with DNA template replaced with sterile PCR-grade water also scored as negative. At last, no false positive or false negative results were detected.

\section{Discussion}

Cff is an important seedborne bacterial phytopathogen, with a high negative impact on the yields of beans as well as of other legumes $[2,4,38,39]$. The increasing worldwide spreading of $C f f$ in bean-producing areas is strongly driven by the global expansion of international trades of plant materials, as well as by the multifaceted impact of climate change on plant-pathogen interaction and on weather conducive conditions [40]. It is important to point out that leguminous crops are essential for food security, as they are a staple food and help fighting hunger in less developed countries, and contribute to healthy eating habits worldwide. Furthermore, legumes have a pivotal role in a sustainable agriculture, and in climate change mitigation. Their symbiotic relationship with nitrogen-fixing rhizobia bacteria allows these crops to strongly improve soil health, and to reduce the expensive and polluting use of synthetic nitrogen fertilizers in agriculture [41]. 
Therefore, more research is urgently needed on these crops, as well as on their most important diseases and pathogens, including Cff. As it occurs in other seedborne phytopathogens, the availability of accurate and highly specific seed health tests is among the most important and essential means of control for Cff. Indeed, dramatic outbreaks can easily be caused by inadequate surveillance and quarantine regulatory procedures, following the entry and establishment of a new and emerging plant pathogen. Indeed, the interception of Cff during a port of entry inspection of plant material is extremely difficult, because Cff-infected seeds are mostly asymptomatic $[1,38]$. Furthermore, the existing assay developed so far for Cff detection on plant material $[16,17]$ requires several specialized equipment and instruments and takes longer times in comparison to other most recent molecular diagnostic approaches such as LAMP [23]. LAMP has also several advantages in comparison to traditional PCR-based approaches, such as its low cost, ease in use, and suitability for in-field/on-site testing.

The only challenging step of the LAMP approach is the correct design of effective primers. Due to the high number of primers needed for each primer set, and the limited options as far as target sequences are concerned, the risk related to the formation of secondary structures can be high. In this paper, we present the development of a LAMP assay for the specific detection of Cff. The newly developed assay targets the unique and highly conserved $306 \mathrm{bp}$ sequence, that was successfully used for the design of the PCR-based assay for Cff and widely applied for in planta testing [16,17].

The optimized conditions established for the Cff-specific LAMP detection are $63^{\circ} \mathrm{C}$ as amplification temperature, and $30 \mathrm{~min}$ as running time. The analytical sensitivity of the LAMP assay for Cff detection is $100 \mathrm{fg} /$ reaction, which was detected by real-time fluorescence monitoring after $20 \mathrm{~min}$, with $5 \mathrm{~min}$ needed to detect $100 \mathrm{ng} /$ reaction. The sensitivity was further confirmed by tests carried out on Cff-infected plant samples. The four LAMP primer set here designed was thus demonstrated to be highly performant, without loop primers, that sometimes have been reported to cause unwanted instability in amplification [42,43].

Lastly, a procedure was developed to visualize LAMP amplification easily and directly through naked eyes, $30 \mathrm{~min}$ after isothermal incubation of samples. The colorimetric $\mathrm{pH}$-sensitive indicator used here allowed the avoidance of the usual drawbacks related to other colorimetric indicators, often producing false-positive results [44-46]. To the best of our knowledge, this is the first time that a LAMP assay was developed for the specific quali-quantitative detection of Cff. This LAMP assay provides a reliable, specific, and sensitive testing procedure, able to reveal the presence of Cff DNA on bean seeds and other plant materials, rapidly and with the naked eye, thus substantially reducing the risk of disease outbreaks by Cff due to its early detection.

Supplementary Materials: The following are available online at http://www.mdpi.com/2076-2607/8/11/1705/s1, Figure S1. Location of annealing sites of the four Cff-specific LAMP primers here designed on the target sequence. Table S1: Free Energy $(\Delta \mathrm{G} ; \mathrm{kcal} / \mathrm{mol})$ values for cross-dimers combination, and for self-dimers and harpins formation for the Cff LAMP primers designed in this study.

Author Contributions: Conceptualization and experiment design, S.T. and C.B.; investigation and data analysis, C.B.; S.T.; A.N.I.; writing—original draft preparation, S.T.; C.B.; writing-review and editing, S.T.; C.B.; E.O.; A.N.I.; supervision, project administration and funding acquisition, S.T. All authors have read and agreed to the published version of the manuscript.

Funding: This research was funded by Università di Firenze, DAGRI, FAI (Fondo per internazionalizzazione, AA2017, AA2020), by Ministero Italiano della Difesa, Progetto SFINGE (ref. $n^{\circ}$ 2074/16.12.2019), and by Fondazione Cassa di Risparmio di Firenze (ref 2019/46076).

Acknowledgments: Thanks are due to Silvia Calamai and Matteo Cerboneschi for the helpful discussions, and their comments and suggestions made on previous drafts.

Conflicts of Interest: The authors declare no conflict of interest. The funders had no role in the design of the study; in the collection, analyses, or interpretation of data; in the writing of the manuscript, or in the decision to publish the results. 


\section{References}

1. EPPO. Curtobacterium flaccumfaciens pv. flaccumfaciens. Bull. OEPP 2011, 41, 320-328.

2. EFSA Panel on Plant Health (EFSA PLH Panel); Jeger, M.; Bragard, C.; Caffier, D.; Candresse, T.; Chatzivassiliou, E.; Dehnen-Schmutz, K.; Gilioli, G.; Grégoire, J.-C.; Miret, J.A.J.; et al. Pest categorisation of Curtobacterium flaccumfaciens pv. flaccumfaciens. EFSA J. 2018, 16, 5299.

3. Hedges, F. A bacterial wilt of the bean caused by Bacterium flaccumfaciens nov. Science 1922, 55, $433-434$. [CrossRef] [PubMed]

4. Osdaghi, E.; Young, A.J.; Harveson, R.M. Bacterial wilt of dry beans caused by Curtobacterium flaccumfaciens pv. flaccumfaciens: A new threat from an old enemy. Mol. Plant Pathol. 2020, 21, 605-621. [PubMed]

5. EPPO Global Database. Curtobacterium flaccumfaciens pv. flaccumfaciens (CORBFL). Categorization. 2020. Available online: https://gd.eppo.int/taxon/CORBFL/categorization (accessed on 28 October 2020).

6. EPPO. EPPO Standard PM 1/2(28). EPPO A1 and A2 Lists of Pests Recommended for Regulation as Quarantine Pests. 2019. Available online: https:/gd.eppo.int/taxon/CORBFL/documents (accessed on 28 October 2020).

7. European Commission. Implementing Regulation (EU) 2019/2072. Official Journal of the European Union. 2019. Available online: https://eur-lex.europa.eu/legal-content/EN/TXT/PDF/?uri=CELEX:32019R2072\& from $=\mathrm{EN}$ (accessed on 28 October 2020).

8. Bastas, K.K.; Sahin, F. Evaluation of seedborne bacterial pathogens on common bean cultivars grown in central Anatolia region, Turkey. Eur. J. Plant Pathol. 2016, 147, 239-253. [CrossRef]

9. González, A.J.; Tello, J.C.; Rodicio, M.R. Bacterial Wilt of Beans (Phaseolus vulgaris) Caused by Curtobacterium flaccumfaciens in Southeastern Spain. Plant Dis. 2005, 89, 1361. [CrossRef]

10. Sammer, U.F.; Reither, K. Curtobacterium flaccumfaciens pv. flaccumfaciens on soybean in Germany-A threat for farming. J. Phytopathol. 2012, 160, 314-316.

11. Eurostat. The Future of Food and Farming for a Flexible, Fair and Sustainable Common Agricultural Policy. European Commission Press Release Database 2017. Available online: https://ec.europa.eu/eurostat (accessed on 28 October 2020).

12. Hedges, F. Bacterial wilt of beans (Bacterium flaccumfaciens Hedges) including comparison with Bacterium phaseoli. Phytopathology 1926, 16, 1-22.

13. Hsieh, T.F.; Huang, H.C.; Erickson, R.S. Bacterial wilt of common bean: Effect of seedborne inoculum on disease incidence and seedling vigour. Seed Sci. Technol. 2006, 34, 57-67. [CrossRef]

14. Camara, R.C.; Vigo, S.C.; Maringoni, A.C. Plant to seed transmission of Curtobacterium flaccumfaciens pv. flaccumfaciens in a dry bean cultivar. J. Plant Pathol. 2009, 91, 549-554.

15. Guimaraes, P.M.; Palmano, S.; Smith, J.J.; Grossi, M.F.S.; Saddler, G.S. Development of a PCR test for the detection of Curtobacterium flaccumfaciens pv. flaccumfaciens. Antonie Van Leeuwenhoek 2001, 80, 1-10. [CrossRef] [PubMed]

16. Tegli, S.; Sereni, A.; Surico, G. PCR-based assay for the detection of Curtobacterium flaccumfaciens pv. flaccumfaciens in bean seeds. Lett. Appl. Microbiol. 2002, 35, 331-337. [CrossRef]

17. Tegli, S.; Cerboneschi, M.; Vidaver, A.K. Detection of Curtobacterium flaccumfaciens pv. flaccumfaciens in bean seeds and in seeds of other Leguminosae crops. In Detection of Plant-Pathogenic Bacteria in Seed and Other Planting Material, 2nd ed.; Fatmi, M., Walcott, R.R., Schaad, N.W., Eds.; APS Press: St Paul, MN, USA, 2017; pp. 77-83.

18. Deuner, C.C.; Magela, R.S.; Zacaroni, A.B.; Figueira, A.R.; Camera, J.N. Sensitivity of the method of obtaining bacterial cells and PCR for detection of Curtobacterium flaccumfaciens pv. flaccumfaciens in bean seeds. Summa Phytopathol. 2012, 38, 48-53. [CrossRef]

19. Gonçalves, R.M.; Schipanski, C.A.; Koguishi, L.; Soman, J.M.; Sakate, R.K.; Silva Júnior, T.A.F.; Maringoni, A.C. Alternative hosts of Curtobacterium flaccumfaciens pv. flaccumfaciens, causal agent of bean bacterial wilt. Eur. J. Plant Pathol. 2017, 148, 357-365.

20. Osdaghi, E.; Taghavi, S.M.; Hamzehzarghani, H.; Fazliarab, A.; Harveson, R.M.; Tegli, S.; Lamichhane, J.R. Epiphytic Curtobacterium flaccumfaciens strains isolated from symptomless solanaceous vegetables are pathogenic on leguminous but not on solanaceous plants. Plant Pathol. 2018, 67, 388-398. [CrossRef] 
21. Osdaghi, E.; Taghavi, S.M.; Calamai, S.; Biancalani, C.; Cerboneschi, M.; Tegli, S.; Harveson, R.M. Phenotypic and molecular-phylogenetic analysis provide novel insights into the diversity of Curtobacterium flaccumfaciens. Phytopathology 2018, 108, 1154-1164. [CrossRef] [PubMed]

22. Nascimento, D.M.; Oliveira, L.R.; Melo, L.L.; Silva, J.C.; Soman, J.M.; Girotto, K.T.; Eburneo, R.P.; Ribeiro-Junior, M.R.; Sartori, M.M.P.; Silva Júnior, T.A.F.; et al. Survival of Curtobacterium flaccumfaciens pv. flaccumfaciens in weeds. Plant Pathol 2020, 69, 1357-1367. [CrossRef]

23. Notomi, T.; Okayama, H.; Masubuchi, H.; Yonekawa, T.; Watanabe, K.; Amino, N.; Hase, T. Loop-mediated isothermal amplification of DNA. Nucleic Acids Res. 2000, 28, E63. [CrossRef]

24. Chen, Z.D.; Kang, H.J.; Chai, A.L.; Shi, Y.X.; Xie, X.W.; Li, L.; Li, B.J. Development of a loop-mediated isothermal amplification (LAMP) assay for rapid detection of Pseudomonas syringae pv. tomato in planta. Eur. J. Plant Pathol. 2020, 156, 739-750. [CrossRef]

25. Ocenar, J.; Arizala, D.; Boluk, G.; Dhakal, U.; Gunarathne, S.; Paudel, S.; Dobhal, S.; Arif, M. Development of a robust, field-deployable loop-mediated isothermal amplification (LAMP) assay for specific detection of potato pathogen Dickeya dianthicola targeting a unique genomic region. PLoS ONE 2019, 14, e0218868. [CrossRef]

26. Sagcan, H.; Turgut Kara, N. Detection of Potato ring rot pathogen Clavibacter michiganensis subsp. sepedonicus by Loop-mediated isothermal amplification (LAMP) assay. Sci. Rep. 2019, 9, 20393. [PubMed]

27. Sun, M.; Liu, H.; Huang, J.; Peng, J.; Fei, F.; Zhang, Y.; Hsiang, T.; Zheng, L. A Loop-Mediated Isothermal Amplification Assay for rapid detection of Pectobacterium aroidearum that causes soft rot in Konjac. Int. J. Mol. Sci. 2019, 20, 1937. [CrossRef]

28. Elbeaino, T.; Incerti, O.; Dakroub, H.; Valentini, F.; Huang, Q. Development of an FTP-LAMP assay based on TaqMan real-time PCR and LAMP for the specific detection of Xylella fastidiosa De Donno and mulberry strains in both plants and insect vectors. J. Microbiol. Methods 2020, 175, 105992. [CrossRef] [PubMed]

29. Bertani, G. Studies on Lysogenesis I. The mode of phage liberation by lysogenic Escherichia coli. J. Bacteriol. 1951, 62, 293-300. [CrossRef]

30. Vidaver, A.K. Synthetic and complex media for the rapid detection of fluorescence of phytopathogenic pseudomonads: Effect of the carbon source. Appl. Microbiol. 1967, 15, 1523-1524. [CrossRef]

31. Green, M.; Sambrook, J. Molecular Cloning: A Laboratory Manual, 4th ed.; Cold Spring Harbor Laboratory Press: New York, NY, USA, 2012.

32. Hsieh, T.F.; Huang, H.C.; Múndel, H.H.; Scott, E. A rapid technique for screening common bean (Phaseolus vulgaris L.) for resistance to bacterial wilt [Curtobacterium flaccumfaciens pv. flaccumfaciens (Hedges) Collins and Jones]. Rev. Mex. Fitopatol. 2003, 21, 370-374.

33. Zhang, S.Y.; Dai, D.J.; Wang, H.D.; Zhang, C.Q. One-step loop-mediated isothermal amplification (LAMP) for the rapid and sensitive detection of Fusarium fujikuroi in bakanae disease through NRPS31, an important gene in the gibberellic acid bio-synthesis. Sci. Rep. 2019, 9, 3726. [CrossRef]

34. Chen, Q.; Li, B.; Liu, P.; Lan, C.; Zhan, Z.; Weng, Q. Development and evaluation of specific PCR and LAMP assays for the rapid detection of Phytophthora melonis. Eur. J. Plant Pathol. 2013, 137, 597-607. [CrossRef]

35. Edwards, T.; Burke, P.; Smalley, H.B.; Gillies, L.; Longhurst, D.; Vipond, B.; Hobbs, G. Loop-mediated isothermal amplification (LAMP) for the rapid detection of Mycoplasma genitalium. Diagn. Microbiol. Infect. Dis. 2015, 83, 13-17. [CrossRef]

36. Yu, L.; Song, S.; Yu, C.; Qi, L.; Yu, Z.; Jiao, B.; Yang, J. A loop mediated isothermal amplification (LAMP) assay for rapid and reliable detection of Anguina wevelli, a grass parasitic nematode. Eur. J. Plant Pathol. 2018, 150, 725-734. [CrossRef]

37. Tanner, N.A.; Zhang, Y.; Evans, T.C., Jr. Visual detection of isothermal nucleic acid amplification using pH-sensitive dyes. Biotechniques 2015, 58, 59-68. [CrossRef] [PubMed]

38. Harveson, R.M.; Schwartz, H.F.; Urrea, C.A.; Yonts, C.D. Bacterial wilt of dry-edible beans in the Central High Plains of the U.S.: Past, Present, and Future. Plant Dis. 2015, 99, 1665-1677. [CrossRef]

39. Maringoni, A.C.; Ishizuka, M.S.; Silva, A.P.; Soman, J.M.; Moura, M.F.; Silva Júnior, T.A.F.; Chiorato, A.F.; Morais Carbonell, S.A.; Da Silva Fonseca Júnior, N. Reaction and colonization of common bean genotypes by Curtobacterium flaccumfasciens pv. flaccumfasciens. Crop Breed. Appl. Biotechnol. 2015, 15, 87-93. [CrossRef]

40. Velásquez, A.C.; Castroverde, C.D.M.; He, S.Y. Plant-Pathogen warfare under changing climate conditions. Curr. Biol. 2018, 28, R619-R634. [CrossRef] [PubMed] 
41. Ferguson, B.J.; Mens, C.; Hastwell, A.H.; Zhang, M.; Su, H.; Jones, C.H.; Chu, X.; Gresshoff, P.M. Legume nodulation: The host controls the party. Plant Cell Environ. 2019, 42, 41-51. [CrossRef] [PubMed]

42. Pillai, D.; Bonami, J.R.; Sri Widada, J. Rapid detection of Macrobrachium rosenbergii nodavirus (MrNV) and extra small virus (XSV), the pathogenic agents of white tail disease of Macrobrachium rosenbergii (De Man), by loop-mediated isothermal amplification. J. Fish Dis. 2006, 29, 275-283. [CrossRef]

43. Teng, P.H.; Chen, C.L.; Sung, P.F.; Lee, F.C.; Ou, B.R.; Lee, P.Y. Specific detection of reverse transcription-loop-mediated isothermal amplification amplicons for Taura syndrome virus by colorimetric dot-blot hybridization. J. Virol. Methods 2007, 146, 317-326. [CrossRef]

44. Fischbach, J.; Xander, N.C.; Frohme, M.; Glokler, J.F. Shining a light on LAMP assays-A comparison of LAMP visualization methods including the novel use of berberine. Biotechniques 2015, 58, 189-194. [CrossRef]

45. Wong, Y.P.; Othman, S.; Lau, Y.L.; Radu, S.; Chee, H.Y. Loop-mediated isothermal amplification (LAMP): A versatile technique for detection of micro-organisms. J. Appl. Microbiol. 2018, 124, 626-643. [CrossRef]

46. Yao, X.; Li, P.; Xu, J.; Zhang, M.; Ren, R.; Liu, G.; Yang, X. Rapid and sensitive detection of Didymella bryoniae by visual loop-mediated isothermal amplification assay. Front. Microbiol. 2016, 7, 1372. [CrossRef]

Publisher's Note: MDPI stays neutral with regard to jurisdictional claims in published maps and institutional affiliations.

(C) 2020 by the authors. Licensee MDPI, Basel, Switzerland. This article is an open access article distributed under the terms and conditions of the Creative Commons Attribution (CC BY) license (http://creativecommons.org/licenses/by/4.0/). 